\title{
Beautiful Burials, Beautiful Skulls: The Aesthetics of the Egyptian Mummy
}

The American Egyptologist Herbert E. Winlock often livened up his annual excavation reports with a colourful turn of phrase. Even so, 'atrocities of hideousness' stands out in his description of several burials he and his Metropolitan Museum of Art colleagues discovered beneath the dramatic cliffs of Deir el-Bahri in the 1920s (Fig. 1). ${ }^{1}$ Sited on the west bank of the Nile at Luxor, Deir el-Bahri shelters temples of the Middle and New Kingdoms (c. 2000 to 1500 BCE), which were the primary interest of the Metropolitan expedition. One of the inconveniences of archaeology, however, is that later things lie in the way of earlier material, where stratigraphic deposits have accrued over time. Archaeology took more interest in the remains of Egypt's glory days under famous pharaohs than in the centuries when Egypt was part of the Roman empire. While Winlock's team recorded these later burials with the same diligence devoted to other finds, his negative judgement of their aesthetic qualities reflects widespread ideas in 20th-century scholarship about the comparative value of 'provincial' Roman art or the 'decline' of ancient Egyptian art from its earlier pinnacle. Laid directly in the ground, these wrapped-up mummies and their staring covers, painted on coarse-weave, gessoed linen, looked impoverished as well as hideous. Plaster jewels were poor imitations of Byzantine splendour, ancient gods appeared in cartoonish style at the bottom of each cover, and white, black, red, and yellow dominated the colour palette, a drab desert of painterly skill.

Today, one of the few intact examples of these 3rd-century AD mummies rests in a display case in the Metropolitan Museum of Art, after several decades in storage. While still in the field, the museum unwrapped the other mummies it found, documenting the removal of

\footnotetext{
${ }^{1}$ H. E. Winlock, HThe Museum's Excavations at Thebes'H Bulletin of the Metropolitan Museum of Art, Part II, The Egyptian Expedition 1923-1924 (1924), 5-33, at 32. For the burials, see Christina Riggs, 'iggsstinaurials, seepolDeir El-Bahri', Journal of Egyptian Archaeology 86 (2000), 121-144; The Beautiful Burial in Roman Egypt: Art, Identity, and Funerary Religion. Oxford: OUP, 2005, 232-243, 295-301. For a full-colour image of the intact mummy in the Metropolitan Museum of Art, see 'Mummy with a Painted Mask Depicting a Woman Holding a Goblet', The Collection Online $<$ http://www.metmuseum.org/collection/the-collection-online/search/547758 $>$ accessed 4 November 2015.
} 
the wrappings stage by stage in photographs and likely discarding both the textiles and the human remains afterwards. Archaeological records are silent on such details, and mummies have the distinction of being the only discovery that archaeologists have consistently dismantled and destroyed in the process of their work. To modern science (and in the late 19th and early 20th centuries, archaeology self-consciously styled itself as a science in Anglophone scholarship, more strongly than cognate knowledge formations), the primary value of a mummy was in the human corpse beneath the wrappings. Surfaces - especially surfaces as unprepossessing as the Deir el-Bahri covers - offered little interest on either academic or aesthetic grounds. Instead, the body inside held an aesthetic fascination of its own, thanks to the mummy's trajectory through anatomical study, gothic fiction, and forensic science. The Egyptian mummy thus exemplifies the gulf between any ancient aesthetic we can recover through archaeological evidence, and a modern aesthetic with tenacious roots in the colonial encounter between Europe and Egypt.

In this article, I use Egyptian burials of the Roman period as an entry point for considering aesthetics in relation to archaeology, ancient art, and human remains. Although some archaeologists and Egyptologists reject the concept of aesthetics, even the word itself, I argue that a more rounded and reflexive approach to aesthetics in fact complements questions of ontology, materiality, and social practice that concern much contemporary archaeological thought. This in turn allows disparate sources of evidence or method fieldwork, philology, visual analysis - to work together to try to apprehend ancient motivations and experiences. Moreover, engaging with aesthetics requires archaeologists and Egyptologists to reflect critically on disciplinary histories and the legacies they carry. More hideous than Winlock's 'bedizened' dead of Deir el-Bahri is the Egyptian mummy's long embedding in the discursive strategies of racial science, for instance, which this article concludes by contrasting with evidence for the aesthetics of funerary practice in Roman Egypt. Beautiful burials and beautiful skulls lie on either side of the gulf between ancient 
experiences and modern expectations of what an Egyptian mummy is, and is for.

Understanding these as the products of two different aesthetic frameworks shaped by distinct cultures may offer the best way to bridge them.

\section{Aesthetics, Archaeology, Ancient Art}

Many specialists in ancient art either avoid the words 'aesthetic' and 'aesthetics' or use them chiefly in relation to visual perception and the communicative or expressive potential of form. Archaeologists have also tended to reject aesthetics as too laden with Western notions of fine art or refined taste, with their ready assumptions of cultural superiority and elitism. While both perception and the role of form have conventionally been foci of analytic aesthetics in philosophy, the past twenty-five years have seen anthropologists, archaeologists, and ancient art historians, along with philosophers, develop a much broader, less ethnocentric concept of aesthetics that moves beyond subject-object binaries to consider a full range of sensory encounters and engagements with the material world. ${ }^{2}$ Building on the work of anthropologists Jeremy Coote and Anthony Shelton, archaeologist Chris Gosden has called for an understanding of aesthetics as part of the social life of objects, that is, the ways in which objects enable social relationships, the creation and maintenance of social structures, and the circulation and negotiation of social norms. ${ }^{3}$ Sensory experiences, hence aesthetic values, are culturally directed. They derive not from the self-contained, perceiving subject, nor from the object or artwork itself (which is, after all, a cultural creation embedded in experiences), but from our interactions with the material world and - through materiality - the immaterial world as well. In cognitive archaeology, Lambros Malafouris has argued that an emphasis on

\footnotetext{
${ }^{2}$ One such argument within philosophy is Alan H. Goldman, 'old Broad View of Aesthetic Experience', The Journal of Aesthetics and Art Criticism 71:4 (2013), 323-333.

${ }^{3}$ Jeremy Coote and Anthony Shelton (eds), Anthropology, Art and Aesthetics (Oxford: Clarendon, 1992); Chris Gosden, 'osden: Sense: Archaeology and Aesthetics', World Archaeology 33:2 (2001), 163-167; 'Aesthetics, Intelligence and Emotions: Implications for Archaeology', in Elizabeth DeMarrais, Chris Gosden and Colin Renfrew (eds), Rethinking Materiality: The Engagement of Mind with the Material World (Cambridge: McDonald Institute for Archaeological Research, 2004), 32-42.
} 
material engagement offers a corrective to the overly narrow conception of aesthetics dismissed, or misconstrued, by some archaeologists and anthropologists of art. ${ }^{4}$

Two examples may be useful here to illustrate the vexed relationship between aesthetics and the study of archaeology and ancient art. The first stems from my own experience, writing recently for an editor trained in classical archaeology, who questioned my use of the phrase 'aesthetic preferences' in a discussion of sculpture in Roman Egypt; wouldn't 'stylistic' be a better choice than 'aesthetic'? I held out for aesthetic, because judgements about the 'style' of an artwork are judgements that we make, in hopes that they will help us better characterize differences and similarities among our incomplete, selfdefined corpus. What I was suggesting was that certain sculptural features were actors' choices that could be understood as part of a wider aesthetic system rather than simply parsed as X indicates $\mathrm{Y}$, as if an arsenal of academic terms - iconography, style, context - could protect us from the pitfalls of our own admiration, or Winlock-like revulsion, for our objects of study.

My second example is a recently published reference work on ancient Egyptian art, in which just three (of twenty-seven) contributions explicitly consider aesthetics. Contributions to the volume use little or no comparative or theoretical literature, including what seem to this author to be established and significant scholarly voices in the archaeology and anthropology of art. For instance, only one contribution cites Coote and Shelton's volume (required reading on anthropology syllabi for twenty years, and well-known to many archaeologists); none refers to Gosden or other archaeological theorists and ancient art historians engaged with questions of aesthetics, such as Zainab Bahrani. ${ }^{5}$ Instead, a

\footnotetext{
${ }^{4}$ Lambros Malafouris, 'The aesthetics of material engagement', in Riccardo Manzotti (ed.), Situated Aesthetics: Art Beyond the Skin (Exeter: Imprint Academic, 2011), 123-139; see also his How Things Shape the Mind: A Theory of Material Engagement (Boston and London: The MIT Press , 2013).

${ }^{5}$ Melinda K. Hartwig (ed.), A Companion to Ancient Egyptian Art (Malden, MA and Oxford: Wiley Blackwell, 2014). Bahrani's relevant work includes The Graven Image: Representation in Babylonia and Assyria (Philadelphia: University of Pennsylvania Press, 2003); The Infinite Image: Art, Time and the
} 
contribution on 'Reception and perception', which includes a section on aesthetics, proffers an internal dialogue between author Alexandra Verbovsek's own and other Egyptologists' work, and uses a narrow idea of aesthetics focused on questions of beauty and formal effect. ${ }^{6} \mathrm{~A}$ second contribution on 'Style', by editor Melinda Hartwig, similarly conjoins aesthetics and 'the formal aspects of a work of art'. ${ }^{7}$ The contribution that does point readers to Coote and Shelton's work, by Egyptologist John Baines, opens the volume by posing the ontological question 'What is art?'. 8 That this question needed its own chapter, in a volume devoted to art, speaks to the crisis of confidence that seems to dog the study of visual and material culture in Egyptology, and to the insularity of Egyptian art studies in comparison to ancient Greek, Roman, and Near (or Middle) Eastern art.

Baines' answer to 'What is art?' is to take 'the aesthetic' as his basis for interrogating the context, creation, and performative enactment of art in ancient Egypt; in this way, he aims for a broader, more inclusive scope than that adopted elsewhere in the same volume. As he points out, the material record recovered through - I would say, created by - archaeology is a starting point, but apprehending the full significance of aesthetic concerns in ancient society requires us to think beyond that record, to the kinds of experiences that do not necessarily survive in a physical state. Western theories of art, especially since the 18th century, have defined 'art' as something - a book, a piece of music, a painting - that produces an aesthetic effect or experience because it has been designed to do so. This culturally specific definition, often assumed to parallel ancient Greek categorizations, arguably reduces 'the ancient world'

Aesthetic Dimension in Antiquity (Reaktion/University of Chicago Press, 2014); and 'Assyro-Babylonian Aesthetics', in Michael Kelly (ed.), The Oxford Encyclopaedia of Aesthetics, 2nd edn (Oxford: OUP, 2014). Perhaps tellingly, editors have not included an entry concerned with ancient Egyptian aesthetics in either edition of the Oxford Encyclopaedia of Aesthetics.

${ }^{6}$ Alexandra Verbovsek, 'Reception and perception', in Hartwig (ed.), Companion to Ancient Egyptian Art, 141-154, section on aesthetics at 147-149.

${ }^{7}$ Melinda K. Hartwig, 'Style', in Hartwig (ed.), Companion to Ancient Egyptian Art, 39-59, quoted passage at 45. Hartwig situates her discussion of style within semiotics and communications theory, rather than the extensive literature on style in art history, archaeology, and philosophy, on which see the overview by Stephanie Ross, nie 45. Hartwig in Jerrold Levinson (ed.), The Oxford Handbook of Aesthetics (Oxford and New York: OUP, 2005), 228-239.

${ }^{8}$ John Baines, 'What is Art?', in Hartwig (ed.), Companion to Ancient Egyptian Art, 1-21. 
to a literate male elite in Classical Athens. ${ }^{9}$ Beyond Plato's cave, the misapprehension of aesthetics as a matter of visual perception, or a standard of beauty, owes as much to 18th and early-19th century philosophy (Baumgarten, Kant, Hegel) as it does to the enduring influence of Clive Bell's 'significant form'. The formulation of a modernist aesthetic coincided with important publications on Egyptian art (e.g. by Heinrich Schäfer and Jean Capart) and with changes in collecting and display practices in the early 20 th century. ${ }^{10}$ As with ethnographic art, non-Western art from the distant past seemed to invite connoisseurial appraisal, 'elevating' it to the status of 'art' in Western mode and separating it from questions of context and provenance that had been archaeology's defining characteristic. Today, neuroaesthetics and other scientistic approaches to art and aesthetics often echo the easy universalism of 'significant form', especially when generalizing from a few restricted examples, as if the Chauvet cave and Picasso were unproblematically sublime. ${ }^{11}$

Like Gosden and Malafouris, I see the relationship between the artwork and its aesthetic values as inherently fluid, created as it is within social, material, and historical networks. An object develops aesthetic qualities because of what it does, not (or not only) because of how it looks, and the ontology of the object likewise incorporates this social and temporal dimension. As Bahrani argues for ancient Mesopotamian art, a statue in human-like form functioned as a representation not through mimetic resemblance, which has been a

\footnotetext{
${ }^{9}$ This is the approach in James O. Young, 'The Ancient and Modern System of the Arts', British Journal of Aesthetics 55:1 (2015), 1-17, for instance. For an alternative view (with a broader perspective than Young, whose focus is Paul Oskar Kristeller's 1951 study The Modern System of the Arts), see Larry Shiner, The Invention of Art: A Cultural History (Chicago: University of Chicago Press, 2001). Discussion of the ancient Greek evidence: Jeremy Tanner, er $\square \square \leq$ ن 辏 $ب \square \square$ 椐 and Art History Writing in Comparative Historical Perspective', Arethusa 43:2 (2010), 267-288; The Invention of Art History in Ancient Greece: Religion, Society and Artistic Rationalisation (Cambridge: Cambridge University Press, 2009).

${ }^{10}$ SchäSch'ScVon ägyptischer Kunst (Leipzig: J. C. Hinrich, 1919), influential in German-speaking Egyptology, was translated into English in 1974 by John Baines. Capart's Leeipz sur l'art égyptien (Liége: Vaillant-Carmanne, 1920), which includes a chapter 'Problems of Egyptian aesthetics', appeared in English in 1928. Capart's work was influential in defining and promoting prehistoric (predynastic) Egyptian objects as 'primitive art' in the early 20th century.

${ }^{11}$ The work of two leading proponents of neuroaesthetics, Semir Zeki and V. S. Ramachandran, is discussed in John Hyman's cogent critique, 'Art and Neuroscience', in Roman Frigg and Matthew Hunter (eds), Beyond Mimesis and Convention: Representation in Art and Science (Dordrecht: Springer, 2010), 245-261.
} 
primary concern of Western art, but through an un-real resemblance that used the material world to look beyond the material, and beyond the horizon of human time. ${ }^{12}$ Egyptian art, too, had another audience in mind, not an embodied viewer who could stand, like we do, in front of a tomb painting and 'read' its messages, or bend over a museum display case to weigh up the relative attractions of a painted mummy cover thick with plaster, pressed over an actual human body whose time horizon uncannily intersects ours.

How, then, can those of us who study and interpret the past today acknowledge, identify, or retrieve the aesthetic experiences of an ancient culture, especially where those might seem so far removed from our own? Perhaps the museum display case is an apt metaphor for this challenge, facilitating as it does our unimpeded vision across a gulf of time, place, and being. Yet if we do not at least attempt to recover something of ancient aesthetic concerns, we do ourselves and our objects of study a disservice. The archaeological object demands and deserves aesthetic consideration on as near as we can get to its own terms, not only as an approach to modelling the ancient past, but as a corrective to our own aestheticization of that past, which may be diametrically opposed. Aesthetics need not, and should not, be an etic exercise, the outsider always looking in through the distancing glass. Archaeological evidence does offer ways to see insiders looking at themselves, and in the next section, I return to the burials of Roman Egypt to consider how enactment, form, and materiality can each help us apprehend the aesthetics of ancient funerary practices.

\section{Beautiful Burials}

One reason for Winlock's dismissive attitude to the third-century AD burials at Deir el-Bahri was the relative simplicity of their deposition, compared to earlier Egyptian practice. However, the enactment of burials was always more varied than the presumed Egyptian norm

\footnotetext{
${ }^{12}$ Bahrani, Infinite Image, esp. at 67-69, but the discussion is sustained throughout the volume.
} 
of a rock-cut or constructed tomb with an exterior chapel or commemorative marker; this was a norm only for certain elites at certain periods and places. Throughout Egyptian antiquity, some forms of corpse disposal either left no archaeological trace or have not been recovered through excavations to date. ${ }^{13}$ The Roman burials at Deir el-Bahri were laid directly in the ground in shallow pits, either individually or in small groups. Apart from the wrapping and adornment of the embalmed body, and a basket or broken amphora placed over the head of a few burials, nothing else was found in the graves. In the Roman period, this pattern of deposition was not uncommon. Grave goods were minimal, and bodies were often cached in communal tombs overseen by cemetery caretakers, some of whom combined the roles of administrators, gravediggers, and ritualists. ${ }^{14}$ Depending on the locale, burials were made in simple pits or in fresh, purpose-built tombs cut into cliffs or bedrock, or else they might be inserted into much older tombs, reclaiming and reusing venerated space. Some cemeteries associated with urban centres did have tomb superstructures, with bodies placed under the floor or set into niches, but these appear to have been more rare, or at least not as well preserved..$^{15}$ In thinking about funerary practices in Roman Egypt, then, one of the first points to acknowledge is that communal burial was widely practiced, and even individual graves were dug in close proximity to each other, sometimes overlapping earlier burials. Even if the specific deposition of the corpse was a decision left to cemetery workers, rather than the mourners, communality and simplicity (as we might characterize the paucity of grave goods) must have had a positive, or at least neutral, aesthetic value. ${ }^{16}$

\footnotetext{
${ }^{13}$ John Baines and Peter Lacovara, 'Burial and the Dead in Ancient Egyptian Society: Respect, Formalism, Neglect', Journal of Social Archaeology 2 (2002), 5-36.

${ }^{14}$ Tomasz Derda, rdasz)of Social ArchaeoGraeco-Roman Egypt in the Light of the Greek Papyri', Journal of Juristic Papyrology 21 (1991), 13-36.

${ }^{15}$ For example, Katja Lembke, 'City of the Dead: Tuna el-Gebel', in Christina Riggs (ed.), The Oxford Handbook of Roman Egypt (Oxford: OUP, 2012), 205-222.

${ }^{16}$ Practices varied over time and by region, but for the cemetery workers known as choachytes, active in the Theban region in the Ptolemaic period, see P. W. Pestman, The Archive of the Theban Choachytes (Leuven: Peeters,1993).
} 
Moreover, in Egyptian practice, the enactment of a burial extended both before and beyond the deposition of the body. The ideal length of time devoted to embalming and wrapping a corpse was seventy days, correlated in ritual texts to the length of time the decan constellations were visible in the night sky. ${ }^{17}$ Although not every body received a complete mummification, by any means, some form of embalming enabled a prolonged performance of mortuary and mourning activities. Gaps of days, weeks, or many months could pass between the time the mummy was prepared and the date when it was placed in the grave or tomb, suggesting that a separation of ritual activities was not unusual. ${ }^{18}$ Papyrological documents hint at stages such as an initial washing and laying out of the body at home, delivery to the embalmers three or four days after death, and a funeral banquet and procession, but it is difficult to say anything much more precise. ${ }^{19}$ What scholars can say is that funerary practices reflect and enable an array of aesthetic choices, which are not about 'providing for the afterlife' in the rather simplistic way that much Egyptological literature and museum displays would have it. ${ }^{20}$ They are also not so much about the preservation of a bounded individual identity but about the commemoration, and re-creation, of a social one, a caveat that applies all the more so where certain individuals were singled out for particular care in terms of the embalming and wrapping of the body and its adornment with masks, shrouds, or coffins. Such examples are exceptional, but nevertheless, they can help us understand the sensory, visual, and material world that produced them, and thus, the ancient actors' aesthetic intent.

\footnotetext{
${ }^{17}$ Maarten J. Raven, 'Egyptian Concepts on the Orientation of the Human Body', Journal of Egyptian Archaeology 91 (2005), 37-53 (at 49-50).

${ }^{18}$ Relevant discussion in Walter Scheidel, 'The Meaning of Dates on Mummy Labels: Seasonal Mortality and Mortuary Practice in Roman Egypt', Journal of Roman Archaeology 11 (1998), 28592.

${ }^{19}$ For an overview of such practices, using Greek-language evidence from the period, see Dominic Montserrat, 'ontserratrview of such practicesFayum', in M. L. Bierbrier (ed.), Portraits and Masks (London: British Museum Press, 1997), 33-44.

${ }^{20}$ Thus also Alice Stevenson, 'tevenson Alice MuPredynastic Egyptian Burial: Funerary Performances in the 4th millennium BC', Archaeological Review from Cambridge 22:1 (2007), 75-91.
} 
From a different site and an earlier date, another Roman-period burial in the Metropolitan Museum of Art exemplifies this exceptionality: even Winlock could not have characterized the mummy of Artemidora as hideous, with its gilded adornments, rich colours, and plaster mask, moulded to resemble a lifelike head (Fig. 2). ${ }^{21}$ The naturalistic mask and a Greek epitaph at the foot end of the mummy, identifying the deceased as 'Artemidora, daughter of Sarapion, died untimely aged 27', lend this body a more immediate impact, to modern eyes, than the wrapped body from Deir el-Bahri, and to some extent, this distinction reflects differences in social status and milieu. Unlike the Deir el-Bahri burials, which are drawn from a village population in the south of Egypt, the mummy of Artemidora was found in a communal tomb at Meir in Middle Egypt, a cemetery that served a provincial town nearby, in a region better connected to trade and commerce and more intensively settled over the centuries by immigrants from the Greek world. In terms of the performance and enactment of funerary rites, Artemidora's mummy probably shares much in common with the mummy from Deir el-Bahri, but as a more elaborate example, I use it here to address two further insights it may offer into an ancient aesthetic system, which I discuss in terms of form and materiality.

To start with the question of form - whose concern with outer surface and shape has vexed so much discussion of aesthetics - let us consider first the distinctive shape of the mummy, with its smooth and rounded contours; tall, shaped foot end; and masked head end. The same form is attested for other wrapped mummies and wooden coffins, all from the region of middle Egypt between the Fayum basin and Asyut, and all dating to the 1st and 2nd centuries $\mathrm{AD} .{ }^{22}$ The exaggerated foot end, which stands nearly a metre high on the Artemidora example, is matched by the extended length of the entire mummy, which, at almost two

\footnotetext{
${ }^{21}$ Christina Riggs, The Beautiful Burial in Roman Egypt: Art, Identity, and Funerary Religion (Oxford OUP, 2005), 110-125. For full-colour images, see 'Mummy of Artemidora', The Collection Online $<$ http://www.metmuseum.org/collection/the-collection-online/search/547696 $>$ accessed 11 November 2015. ${ }^{22}$ See Riggs, Beautiful Burial, 105-29 passim, 247-250; Dieter Kurth, Der Sarg der Teüer : Eine Studie zum Totenglauben im römerzeitlichen Ägypten (Mainz: Philipp von Zabern, 1990).
} 
metres, is almost a third longer than the corpse itself. Most of what we see comprises some hundreds of metres of linen textiles layered and wrapped around the body inside, so that the corpse becomes an inner core deep within a sacred bundle. These textiles, which were essential to the ritual of mummification, linked the deceased's lifecycle to his or her family and community, comprising as they did clothing and household linen owned by the dead person and donated by family and associates. ${ }^{23}$ Only pure linen could be used as wrapping material, and by preference cloth that had not been dyed or decorated. Where linen had to be purchased for a burial, the expense represented a substantial outlay, perhaps ten times the annual earnings of a skilled craftsman. On the mummy of Artemidora, the padded, bulky form of the wrappings created the tall foot projection as well as a head end curved exactly to fit into the hollow of the richly gilded, painted, and inlaid mask. The embalmers and mask-makers must have worked in tandem to create this effect, likewise the smaller pieces of stuccoed linen that decorate the sides and foot area of the wrappings.

The mask itself represents Artemidora in contemporary clothing, heavy jewellery, and a Roman imperial hairstyle, which merges with the luxuriant long curls of an Egyptian goddess to emphasize the divine qualities that mummification brought out in the dead. Around the sides and back of the mask, a procession of gods culminates at the crown of the head with the resurrection of Osiris, the god-king whose death and embalming anchored Egyptian funerary mythology. The content and design of this composition makes clear reference to temple decoration; similarly, the tall foot end of the mummy, with its curved and flared upper edge, echoes the shape of shrine roofs and commemorative stelae. At each end of the mummy, the outer forms thus create their own sacred structure around the body, in effect providing a tomb for the wrapped or coffined mummy even in a communal space such as the one where Artemidora was buried. These architectonic forms and decorative references also

\footnotetext{
${ }^{23}$ For the use and significance of textiles in mummification, see Christina Riggs, Unwrapping Ancient Egypt (London: Bloomsbury, 2014), 19-27, 109-151.
} 
treat the wrapped body like the sacred image it is, since Egyptian statues of the gods were kept in shrines even when carried outside the temple for festival processions.

The formal aspects of a burial cannot be separated from this wider network of associations, or from the processes that yield its outer form, such as the supply and wrapping of the textiles. This does not deny that visual splendour was also part of a burial's effectiveness. In the ancient Egyptian language, a burial was often described as either menkhet, 'effective' or neferet, 'beautiful', with an interchangeability suggesting that the two expressions convey similar qualities. A wrapped mummy and its accoutrements - masks, shrouds, coffins - were manifestations of the deceased as something not-of-this-world, created within a set of practices contingent upon the individual's being and relationships inthis-world. Hence questions of form lead to a second, related insight into an ancient aesthetic system, through questions of materiality.

The Deir el-Bahri mummy may look drab in comparison to the mummy of Artemidora, but both most must have transmitted some idea of beauty, through a visual splendour that we can access more equitably by paying closer attention to the materials used in their making. Both the cover on the Deir el-Bahri mummy and the mask and placards on Artemidora's are made in the same way, by adhering coarse-weave linen with gesso and adding further plaster to achieve a sculptural effect. The faces of both were created by pressing them into a mould, to which other moulded elements were then added and hand-finished. The use of plasterwork for burial equipment increased during the Roman period, for reasons that have never been explored in detail. ${ }^{24}$ An improved ability to make plaster (by firing limestone into lime) and to work with it may well have been involved, but the effects that plaster produced - naturalistic facial features, complex hair and jewellery patterns, a surface ready to paint or gild - may also

\footnotetext{
${ }^{24}$ Asja Müller, University of Kiel, is undertaking a doctoral thesis on plaster mummy masks in Roman Egypt, which will help address this and other points about the use of this material.
} 
have struck a chord with contemporary representational preferences, perhaps influenced by the prestige of Classical-style sculpture in the Roman empire.

Plaster-and-linen masks like the Artemidora example, or another female mask that has been removed from its mummy (Fig. 3), display the striking impact of colour and gilding. The latter example, which comes from the Fayum cemetery of Hawara, covers the skin and dress of the deceased with gold leaf. On the Artemidora mask, the skin of the face and arms was originally a bright, gleaming white, to judge by similar coffins and masks; a modern coating appears to have darkened these surfaces. Both gold and bright white conveyed a shining, almost supernatural, gleam, and both were used in Egyptian art to represent the skin of gods. ${ }^{25}$ One of the most striking features of the Artemidora mask is the rich red of the clothing; the gilded mask in Fig. 3 also deployed a deep purple on the tunic stripe, red on the floral bouquet, and bright pink on the back, where Egyptian gods appear. Rather than the red ochre-based pigments used in pharaonic Egypt, these deep shades of red, purple, and pink are likely a form of red lead, a synthetic pigment, known as lake pigment, which was made using madder. ${ }^{26}$ Lake pigments were innovations of this period, and the richer, more durable effects they allowed may have been one factor encouraging the predominance of pinks and reds in funerary art of this era - though the Deir el-Bahri cover reminds us that similar colour results could still be achieved with conventional pigments. Pinks, reds, and purples were likely seen as contiguous, being shades of one colour (red) rather than the distinct colours marked by English vocabulary. For instance, ritual papyri of around this date refer to 'dark red' and 'light

\footnotetext{
${ }^{25}$ For instance, in the paintings on a papyrus known as the Great Harris Papyrus, in the collections of the British Museum: Pierre Grandet, Le Papyrus Harris I (BM 9999) (Cairo: Institut française d'archéologie orientale, 1994); photographs are accessible on the museum website.

${ }^{26}$ Sophie Rowe, Ruth Siddall, and Rebecca Stacey, 'Roman Egyptian Gilded Cartonnage: Technical Study and Conservation of a Mummy Mask from Hawara ', in Julie Dawson, Christina Rozeik, and Margot M. Wright (eds), Decorated Surfaces on Ancient Egyptian Objects: Technology, Deterioration and Conservation (London: Archetype 2010), 106-21.
} 
red' - maroon and pink, in contemporary English? - to describe bandages that the sistergoddesses Isis and Nephthys contributed to embalming. ${ }^{27}$

The use of colour and gilding is intrinsically linked to our visual apprehension of the finished object, but as with the textiles discussed above, the signifying role of different materials, colours, and methods of manufacture are just as important for understanding an aesthetic experience and value system quite different from that of modern societies steeped in Western intellectual traditions. Textiles, which wrapped the dead in an individual as well as a social identity, had visual and tactile qualities whose aesthetic appeal can be judged through the documentary evidence, such as the different grades applied to textiles; so-called royal linen was the most finely spun and woven. The outcome of wrapping rituals in the mummification process was only partly visible, however, with the outermost layer smoothed into the cocoon-like form used for mummies and most coffins since around $2200 \mathrm{BC}$. To be wrapped, as other sacred images were as well, was to be hidden, safe, and preparing for rebirth. The performance of wrapping was seen by no one but the responsible priests, and wrapped forms like the mummy, or its doubles in coffins and divine statues, thus exemplify what Jan Assmann has called an 'aesthetics of secrecy' in ancient Egyptian culture. ${ }^{28}$ Restrictions on viewing were part of this aesthetic system: there is no way to know for certain whether wrapped mummies were ever seen by mourners. If they were, it may only have been fleetingly during a funeral procession, and where a mummy was placed inside a coffin or covered by a catafalque. Even those fleeting glimpses will have been further restricted by factors such as ritual roles, mourners' relationship to the deceased (widows are shown embracing the coffin, for instance), and by the performance itself, with the crowds and

\footnotetext{
${ }^{27}$ E.g. Mark Smith, The Mortuary Texts of Papyrus BM 10507 (London: British Museum, 1987), column VI, lines 14-15.

${ }^{28}$ Jan Assmann, 'Zur Ästhetik des Geheimnisses: Kryptographie als Kalligraphie im Alten Ägypten'y in Aleida Assmann and Jan Assmann (eds), Schleier und Schwelle, I: Geheimnis und Öffentlichkeit (Munich: Wilhelm Fink, 1997), 313-327; see also Riggs, Unwrapping, 163-ß180.
} 
obscured sightlines any large gathering tends to entail. The aesthetic value of a work of art or other cultural practice need not correlate to its visibility.

Yet visibility - whether through the museum display case, or the CT-scanner - now dominates our aesthetic judgement of mummies and other archaeological objects. Since the late 18th century, modern interpretations have transmuted the aesthetics of the Egyptian mummy into an aesthetics not of beauty and of the secret, but of dissection, the forensic, and the relentlessly visible. In the final section of my discussion, I explore the history and legacy of this transmutation, which has turned beautiful burials into beautiful skulls.

\section{Beautiful Skulls}

Many museum collections of Egyptian antiquities bear ample evidence that modern ideas about what a mummy is and is for are very different from ancient ones. From the early modern trade in powdered mumia to the penchant for grisly souvenirs, mummies and fragments of mummies have become part of larger narratives, about the individual presumed to have inhabited the body; about the archaeologists, scientists, or collectors associated with the remains, often in a colonial context; and about ancient Egypt and the Egyptian mummy as tropes of death, disease, danger, the erotic, and the exotic. ${ }^{29}$ But running through all these narratives is something at least as invidious as the cannibalism of mumia consumption or the dismemberment and commodification of human remains: it is the search for the beautiful skull.

Prior to the paradigm shift of the Enlightenment, with its preference for the penetrating gaze, Europeans were disinclined to unwrap Egyptian mummies, which were rarities in collections until the turn of the 19th century. The founding collection of the British Museum included small, intact mummies collected by Sir Hans Sloane and Sir William

\footnotetext{
${ }^{30}$ John Frederick Blumenbach, 'lumenbacherick her references.e to the reviewer's helpfulPhilosophical Transactions of the Royal Society London 84 (1794), 177-195.
} 
Hamilton. These were revealed to be forgeries only in 1792 , when they were unwrapped by Johann Blumenbach, professor of medicine at Göttingen, who presented his results to the Royal Society in London. ${ }^{30}$ Composed of ancient linen neatly arranged around a core of animal or human bones, linen scraps, and debris, such mummies had been acquired in good faith as examples of mummification, because their external appearance matched what Europeans had come to think of as 'a mummy', in the recognizable, smooth-sided form that was already welldocumented.

The absence of human remains inside the British Museum mummies was a particular disappointment, because Blumenbach's chief aim was to make detailed measurements of skulls. His work laid down the fundamental principles of what would become physical anthropology, including the use of craniometry to develop the new concept of race. Blumenbach's doctoral thesis had characterized human 'variety' through five races, identified by skull shape and skin colour, or in his terms, Caucasoid, Mongolian, Ethiopian, American, and Malayan. The Caucasoid group was so named after the Caucasus mountains in Georgia, where what he described as the most beautiful skull he had ever studied, that of a woman, had originated. Blumenbach's work was both the product and promoter of prevailing ideologies, which used race as one way of examining the bewildering differences that confronted Europeans in colonial contact zones. In addition to whatever antiquarian or anatomical insights might be gained from examining mummies more closely, from the late 18th century onwards there was now another incentive for unwrapping Egyptian mummies, whose preserved skin and bones held the promise of further data for the scientific classification of humankind.

In the 1820s, English-Italian obstetrician Augustus Bozzi Granville referred to Blumenbach, Dutch anatomist Petrus Camper, and leading French scientist Georges Cuvier in

\footnotetext{
${ }^{30}$ John Frederick Blumenbach, 'lumenbacherick her references.e to the reviewer's helpfulPhilosophical Transactions of the Royal Society London 84 (1794), 177-195.
} 
presenting his own unwrapping and dissection of an Egyptian mummy to the Royal Society, concluding - like Cuvier - that the Egyptians were Caucasian, like Europeans. Measurements of the skull and pelvis provided all the evidence needed; Granville proved his point by measuring the facial angle of the mummy's profile and comparing its pelvis to that of a 'Negro girl' in his collection of anatomical preparations. ${ }^{31}$ As more mummies entered European collections after the end of the Napoleonic wars and concomitant increase in trade and travel between Egypt and the West, newly styled Egyptologists such as George Gliddon and showman-surgeons like Thomas 'Mummy' Pettigrew turned mummy unwrappings into public spectacle, laying bare on the examination table what ancient Egyptian aesthetics and cultural decorum had expected to remain intact and unseen. ${ }^{32}$ When archaeology emerged as a self-consciously scientific discipline in the late 19th century, it ostensibly rejected such showmanship. But the destruction - for that is what it was - of mummified bodies through anatomy continued both in the field and in the metropole. The characterization of race in ancient human remains was taken as given, using the techniques of physical anthropology and Victorian race science. One of the most influential archaeologists working in Egypt, W. M. Flinders Petrie, collected Egyptian skeletal remains for the Eugenics Laboratory established by his friend Francis Galton at University College London, while Petrie's protégée, Margaret Murray, conducted two mummy unwrappings at the University of Manchester in 1908.33

\footnotetext{
${ }^{31}$ Augustus Bozzi Granville, 'ra Essay on Egyptian Mummies, with Observations on the Art of Embalming among the Ancient Egyptians', Proceedings of the Royal Society of London 115 (1825), 269-316; Christina Riggs, 'An Autopsic Art: Drawings of "Dr Granville's Mummy" in the Royal Society Archives', Royal Society Notes and Records 2016, doi: 10.1098/rsnr.2015.0050 [advance online publication].

${ }^{32}$ On Pettrigrew, see Gabriel Moshenska, shenskag“ shenskPettigrew and the Study of Egypt in Early Nineteenth-century Britain', in William Carruthers (ed.), Histories of Egyptology: Interdisciplinary Measures (Abingdon, UK: Routledge, 2014), 201-214. For Gliddon, see Robert J. C. Young, 'Young, J. C. seeutBlack Athena', in Daniel Orrells et al. (eds), African Athena: New Agendas (Oxford: Oxford University Press, 2011), 174-188, at 176-183.

${ }^{33}$ For Petrie and Galton, see Debbie Challis, The Archaeology of Race: The Eugenic Ideas of Francis Galton and Flinders Petrie (London: Bloomsbury, 2013); for the Murray unwrappings, see Samuel J. M. M. Alberti, 'Molluscs, Mummies and Moon Rock: The Manchester Museum and Manchester Science', Manchester Region History Review 18 (2007), 130-154, at 135-139); Kathleen L. Sheppard, 'Between Spectacle and Science: Margaret Murray and the Tomb of the Two Brothers', Science in Context 25: 4 (2012): 525-549; Riggs, Unwrapping, 112-114, 209-213.
} 
Although one of these unwrappings was a public event, attended by local grandees, university students, and the press, Murray emphasized the rigour of the scientific methods applied to studying what was left of the fragile corpses. In the published results, a Manchester physician contributed his conclusion that one of the skeletons was 'negroid' and 'robust', the other 'caucasian' and 'effeminate', this despite hieroglyphic inscriptions on the mummies' coffins identifying them as brothers. Murray and her colleagues knew better.

The evaluation of Egyptian mummies not for their exterior but for their interior is presumed to be a function of scientific advances, but I suggest that we can consider it instead as a question of aesthetics, whereby one aesthetic system has supplanted another, overwriting the values of an ancient culture with the aesthetic forms constitutive of scientific objectivity in our own. ${ }^{34}$ Facial reconstructions of ancient Egyptian mummies offer a contemporary case in point, based as they are in what human rights scholar Thomas Keenan and visual studies scholar Eyal Weizman have called a 'forensic aesthetics'. ${ }^{35}$ Since the 1970 s, techniques for reconstructing the fleshed appearance of a skull have proved to have criminological uses, for instance to help identify victims of murder or war crimes or, in the case Keenan and Weizman discuss, a perpetrator of such crimes, Josef Mengele. But forensic artists also applied these techniques to ancient human remains, first using physical skulls, and more recently CT-scanning, which allows wrapped bodies to be visualised without physically unwrapping them. ${ }^{36}$ The effects are the same, however, with the result that the aesthetic emphasis placed on Egyptian mummies in museums and the media today focuses almost entirely on the physicality of the corpse - quite the opposite of the ancient actors' intent. Imaginative reconstructions take the study of skulls much further than Blumenbach and

\footnotetext{
${ }^{34}$ On visualisation and objectivity in the sciences, see Lorraine Daston and Peter Galison, Objectivity (Brooklyn: Zone Books, 2007).

${ }^{35}$ Thomas Keenan and Eyal Weizman, Mengele's Skull: The Advent of Forensic Aesthetics (Berlin: Sternberg Press, 2012); Riggs, Unwrapping, 209-213.

${ }^{36}$ Caroline Wilkinson, Forensic Facial Reconstruction (Cambridge: Cambridge University Press, 2008); John Prag and Richard Neave. Making Faces: Using Forensic and Archaeological Evidence (London: British Museum Press, 1997).
} 
Granville, or Petrie and Galton, could ever have anticipated, though all would recognize the discourse of race science in which such reconstructions are enmeshed. The recent reconstruction of two Roman-period mummies at a Canadian university museum offers a case in point (Fig. 4). ${ }^{37}$ The accompanying press release, picked up by websites such as

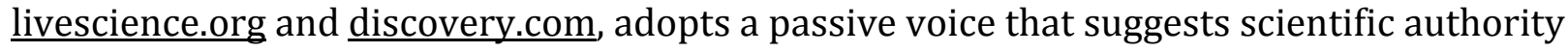
and defers responsibility for the inevitable questions of race such reconstructions raise:

Egyptian tissue depth data derived from ultrasonic imaging of modern Egyptians were used to flesh out the faces. A diversity of skin tone is shown to reflect the Mediterranean, North African, and Sub-Saharan mixture of the Egyptian population as noted throughout history. Hairstyles were pulled from earlier anthropology reports and detected through the wrappings worn by one of the mummies [emphasis added]. ${ }^{38}$

Press coverage, the responsible artist, and, judging by its website, the museum's own exhibition, all present such 'data' as unproblematic, likewise the technique itself. ${ }^{39}$ Yet such facial reconstructions rely on soft tissue depth data that are often outmoded, and always open to interpretation, likewise judgements about what skin colour, age and gender features, and hairstyles or clothing to represent. ${ }^{40}$ Photographs and videos of facial reconstructions in progress, with depth markers plugged into the modelling matrix, or of mummies being CT-

\footnotetext{
${ }^{37}$ A third mummy dated to around the 1st cent BC; strangely, the museum seems to have thought all three dated to the much earlier New Kingdom. Online coverage: Neale McDevitt, 'Facial Reconstructions Bring Redpath Mummies to Life' <http://publications.mcgill.ca/reporter/2014/01/facial-reconstructions-bringredpath-mummies-to-life/>; 'The Faces of Egyptian Mummies Revealed', < http://www.livescience.com/26574-egyptian-mummy-facial-reconstructions.html >; Jennifer Viegas, 'Mummies' Faces, Hairdos, Revealed in 3D' $<$ http://news.discovery.com/history/ancient-egypt/mummyfaces-hairdos-revealed-in-3d-pictures-130125.htm>; Victoria Lywood, 'The Mummies' $<$ http://www.victorialywood.com/The Mummies.html $>$ all accessed 11 November 2015. 38 'p://sc Life After Death', news release $<$ https://www.mcgill.ca/newsroom/channels/news/facing-life-afterdeath-224567> accessed 11 November 2015.

${ }^{39}$ Redpath Museum, 'Exhibits', Third Floor, World Cultures Exhibits $<$ https://www.mcgill.ca/redpath/node/15/exhibits $>$ accessed 11 November 2015.

${ }^{40}$ See discussion in Susan Hayes, 'ayesnscussion inember 2015.h/node/15/exhibits15/exhibits"hibits $<$ th2Museum Management and Curatorship (2015) DOI 10.1080/09647775.2015.1054417.
} 
scanned by white-robed and nitrile-gloved attendants, reinforce an unassailable scientific way of seeing Egyptian mummies and 'doing' science with and to them.

Readers of the Canadian museum bulletins online were not afraid to question at least some of this science, where race was concerned. Comments on the livescience.com and discovery.com websites focused not on the gilding, the pink and red paint, or the linen wrappings of the intact mummies, which were barely illustrated, but on the peachy-pink skin tone of the reconstructions. The Roman date of the mummies informed these below-the-line debates, which engage with tropes of 'invasion' (as the contributors themselves couch it) first by Greeks and Romans, later by Arabs. These 'invasions' are marshalled in a range of arguments, grouped roughly around one of the following themes: that the black or subSaharan population of ancient Egypt disappeared in Greco-Roman times; that the skin tone of the ancient population may have been darker than the pre-'invasion' population, but was never black or sub-Saharan; or that the modern population is exactly the same as the ancient population, give or take a shade of tan. The modern population of Egypt is itself presumed to be a stable, homogeneous entity in all these discussions, as are the ancient populations of different historical eras. In the discourse of ancient Egypt and race (or ethnicity, a term some commentators use imprecisely, to avoid 'race'), debates and evidence from much earlier scholarship live on outside their original, academic fora - unsurprisingly, since the academic and the popular or spectacular share discursive terrain. References that online commentators make to other scientific methods, such as DNA haplotype and genome maps, only underscore the permeation of science and its aesthetics in contemporary life.

How much more persuasive is a CT-scanner or a double-helix than a body wrapped in old linen, a piece of plaster flashy with gilding or red paint, or a wide-eyed face from a sparse grave, whose lack of appeal many Egyptologists might quietly concede. Two centuries of scientistic research on Egyptian mummies have replaced an ancient aesthetic system, based on its own values of secrecy and splendour, with a modern system in which technologies of 
revelation yield evidence so dazzling that the objectivity of science cannot be in doubt. Forensic aesthetics, to borrow Keenan and Weizman's phrase, revisits a discourse of race that has been visualised and aestheticized using ancient Egyptian mummies since the late 18th century. From Blumenbach's beautiful skull, to Camper and Cuvier's facial angles, to the refleshing of CT-scans, the modern, Western valuation of an Egyptian mummy has focused on the corpse within the wrappings. The inward gaze of anatomical science goes beneath the surface in one sense, but only to find a different surface to explore. With its own powerful and persuasive aesthetic, science denies the mummy the aesthetics of completeness and concealment that were intrinsic to its original design.

Recognizing the aesthetic values in which we ourselves are naturalised - significant form, forensic science - is prerequisite to approaching the aesthetics of other cultures in the archaeologically recovered past. I have used individual Roman period burials from Egypt to exemplify the gulf between ancient aesthetic values and our own aesthetic valuation of archaeological objects, in particular human remains. 'Objects' and 'human remains' are our categories, of course, and ancient Egyptian evidence suggests that mummies were akin not to any human beings but to sacred images with an otherworldly, extra-temporal existence. In tracing some of the aesthetic principles I think we can see at work in the Roman period Egyptian funerary sphere, I am thus aware that the ancient actors may not have articulated aesthetic principles in terms of sensory perception, as modern parlance might couch it, but as a manifestation of supernatural effects arising not within the body's senses, but without. This does not hamper the usefulness of aesthetics as a category of analysis, a tool for thinking about the past and our relationship with it. In ancient Egypt, as articulated here through the Roman period that has been my focus, aesthetic choices can be identified in the enactment of burial rites and emplacements, the formal resonances of mummy wrappings and related objects, and the materiality of elements such as textiles and pigments (to name just two) that 
contributed to the creation of the beautiful burial. Foregrounding aesthetics in archaeology demonstrates that 'beauty' goes beyond the Kantian sublime or Bell's significant form. No aesthetic is a universal value, nor should aesthetics comprise only a surface encounter. Material engagements, cultural contexts, and social performances contribute to, and are reshaped by, aesthetic systems that are not our own, but that are also not beyond our grasp. 